\title{
Job Placement: Gender Differences and Consequences on Welfare*
}

\author{
Ricardo Paes de Barros**
}

Carlos Henrique Corseuil ${ }^{* * *}$

Daniel Domingues dos Santos****

Sérgio Pinheiro Firpo******

\section{Abstract}

In the recent period, the qualitative dimension of the women participation in the labor force has improved quickly, in response to cultural and economic changes. In Brazil, many authors have pointed that women have a higher level of schooling than men, which should result, ceteris paribus, in better professional opportunities. However people claim that it is not observed neither in Brazil nor anywhere else, which results in a welfare loss. It's interesting to study how the welfare would change if the women and men have the same chances in the job market. In this paper, we propose how to simulate this hypothetical world. We found that the increase in the women's participation in the labor market would generate just an insignificant effect over the familiar welfare.

\section{Resumo}

No período recente, a participação das mulheres na força de trabalho tem melhorado rapidamente, de maneira qualitativa e quantitativa, em resposta a mudanças culturais e econômicas. No Brasil, diversos autores têm apontado que as mulheres apresentam nível educacional médio superior ao dos homens, o que deveria resultar, caeteris paribus, em melhores oportunidades de emprego. Esta predição não é, contudo, verificada empiricamente, resultando numa perda de bem estar. A mensuração desta perda é o objeto desta investigação, e será feita através de um exercício contrafactual onde são oferecidas às mulheres chances semelhantes às dos homens no mercado de trabalho. Os resultados, todavia, revelam que a melhora no padrão de inserção feminino no mercado de trabalho têm efeitos bastante limitados sobre o bem estar familiar.

${ }^{*}$ The authors thank Wilson Morgado, Rodrigo Dias and especially Roberta Guedes for intensive computational help. Besides these, the comments made by Francisco León and by anonymous referees of the Brazilian Review of Econometrics were of extreme importance.

**IPEA, rbarros@ipea.gov.br

*** IPEA, kiko@ipea.gov.br

**** IPEA and PUC/RJ, ddsantos@ipea.gov.br

***** UC Berkeley, firpo@econ.berkeley.edu

$\underline{\text { Brazilian Review of Econometrics Rio de Janeiro v.21, } \mathrm{n}^{\mathrm{O}} 1 \text {, pp.137-171 May } 2001}$ 
Job Placement: Gender Differences and Consequences on Welfare

Key Words: Gender discrimination, Income distribution and Poverty .

JEL Code: D63, J71, J31, J16 .

\section{Introduction.}

Several studies have verified that the method of job placement is significantly different for men and women. In the first place, there is a significant wage differential between men and women, even when comparing people with the same qualification level, occupying similar work position and living in the same area (Cavalieri \& Fernandes (1998), Barros et al (1992)). Besides being better paid per hour, men tend to have a larger working day, making the difference between measured income larger. Finally, a high degree of occupational segregation is verified, in other words, most of the work positions tend to be filled mostly by men or by women, mixed occupation being rare. As long as typical occupations of both sexes are of different quality, there is one more factor that generates wage differentials. The existence of such differences in job placement can generate an efficiency cost for society insofar as women, by their human capital endowment, could be employed in better jobs, reaching superior levels of productivity and obtaining, this way, larger revenues.

Taking income as a welfare measure, there are indications that differentiated treatment between men and women in labor market could be leading to a sensitive loss of welfare. The measurement of this eventual loss of welfare in the metropolitan area of So Paulo is the focus of this article.

Specifically, we will be interested in estimating how equalization in job placement men and women would affect (i) the poverty level and the distribution of welfare in society; and (ii) the inadequacy level and distribution of the capacity of income generation in the labor force. 
Although they are related, the impacts of female job placement on welfare distribution and on the distribution of income generation capacity can be quite different. Insofar as family members distribute their resources in an equal way, the welfare of any family member depends on the family per capita income. So, the importance of your own income on welfare is limited to the influence of this income on the total family income. As men and women, in general, tend to live together in families, the unequal treatment between men and women in the labor market, which has a big impact on the distribution of income generation capacity, can have little impact on welfare distribution.

The next section describes the nature of women's job placement in Brazil. The methodology used to estimate the effects of transformations in this process on women's capacity of generating income and on the level of society's welfare is described on the third section. The fourth section presents the results. The last section resumes the principal conclusions of this paper.

2. A short description of the nature of female job placement and of the differentials by gender.

\section{Theoretical preliminaries}

In general, job placement differences are justified by differences of productive characteristics among workers. In this way, workers who are more educated or have more experience tend to occupy better work positions because they possess a larger stock of human capital. In the case of man-woman differential however, it is observed that: even though there is little experience distinction and women are sensibly more schooled, men have obtained better work conditions. The job placement difference between men and women with the same productive characteristics in the labor market may happen for three different reasons. In the first place, the opportunity cost of the time 
spent working can differ for men and women. This is the case if, for social-cultural and biological restrictions or for individual preferences, men and women value in a different way the portion of time spent in non-labor activities (for instance, women with newly born children can insist in breastfeeding them, for cultural reasons, while men can have larger aversion to domestic activities, etc.). Among the several job placement dimensions, this explanation should affect mainly differences in the propensity to participate in the labor market and in the average working day of men and women ${ }^{1}$.

In second place, wage differences between men and women may result from pure and simple discrimination. Discrimination is precisely defined as evidence of unequal treatment for inputs of the same production. It comes from the assumption that sex is neither a productive characteristic of the individual nor is it correlated to other productive characteristics ${ }^{2}$ and that men and women are perfect substitutes in the productive process (Becker, 1957). In this way, any treatment differences, besides the differences of preferences between men and women, may be considered as discrimination. However, discrimination tends to disappear when the firms adopt the behavior of maximizing their profits, because in the discrimination presence there is always the possibility that workers with equal productivity are hired for smaller wages. In this way, it is probable that after some time the quality of female work positions became similar to those of men's. Having faith in that possibility, the results obtained

\footnotetext{
${ }^{1}$ Notice however that the decisions about whether to participate or not in the labor market and the duration of the working day depend on the individual confrontation with the expected return of time spent in work and the opportunity cost of this same time in other activities. Thus, in the presence of sex discrimination or of no-substitutability among male and female labor, women's expected wage if they decide to participate in the labor market can be different from men's. Therefore, differentials of working day and participation rate cannot be fully explained by differences of preferences.

${ }^{2}$ Especially for the non observed, in the case of empiric studies.
} 
in this study can also be interpreted as a plausible scenery for a close future.

Finally, men and women's labor can be seen by the firms as different production factors. In this case, productivity and the amount demanded of men and women with identical stock of human capital can differ according to the complementary degree in relation to the other production factors. This argument is controversial, since it can be interpreted as sexist. In fact, even if there still exists exclusively female or male occupations, it is believed that they are a small portion of the total of vacancies available, and do not affect the labor market significantly. Sachsida \& Laurel (1998) estimated a crossed elasticity of negative demand for feminine labor (which means that an increase in men's average wage causes a reduction in the employment level for women), suggesting complementarity in the Brazilian formal job market for all the educational levels. The authors, however, interpret this result as an evidence of the discrimination in the labor market: men and women would in fact be substitutes but the firms, in a discriminative behavior, would not treat them as such.

The scenery of the Brazilian labor market

Brazil has going through deep economical and cultural changes along the last two decades, in a process that has as one of its characteristics the growing valorization of feminine labor in the labor market. Women's job placement in the labor market improves quantitatively, with an increase on the feminine participation rate, and qualitatively, with women having access to work positions that were reserved for men.

As to the quantitative dimension, Barros et alli (1999) show that the female participation has increased about $15 \%$ per decade in Brazil $^{3}$.

\footnotetext{
${ }^{3}$ This result refers to the comparison of the participation of women with the same age in
} 
In spite of the growth of female participation in the labor market, the proportion of women in working age engaged or looking for engagement in economic activities is still inferior to men's proportion. In fact, as shown in Table 1, female participation in São Paulo was, for the period of 1996-98, on average 28 percentile points below the masculine.

Table 1: Basic labor market indicators

\begin{tabular}{|c|c|c|}
\hline Indicators & Men & Women \\
\hline Participation in the labor force ${ }^{1}$ & 69,97 & 41,97 \\
\hline Unemployment & 6,75 & 8,00 \\
\hline Average duration of unemployment & 6,91 & 10,48 \\
\hline Total hours per week (on average) & 43,43 & 38,98 \\
\hline \multicolumn{3}{|c|}{ Employed's share by total hours per week } \\
\hline Less than 30 hours/week & 6,38 & 14,63 \\
\hline Less than 32 hours/week & 9,63 & 22,74 \\
\hline Less than 36 hours/week & 12,70 & 26,61 \\
\hline Less than 40 hours/week & 15,05 & 29,66 \\
\hline
\end{tabular}

Source: Pesquisa Mensal de Emprego (PME) 1996, 1997 and 1998.

${ }^{1}$ Ratio between the Economically Active Population and the Active Population (everyone older than 10)

Among labor force there aren't great differences in the access to work positions. The differences in the unemployment rate by gender are limited (6,7\% for women and 8,0\% for men), although the average duration of unemployment is considerably larger for women $(10,5$ months) than for men (6,9 months). However, as this phenomenon is not purely related to the supply of jobs but also to the level of exigency of this group to accept the available offers, it is difficult to

different birth cuts. 
interpret a larger duration of unemployment as evidence of a larger deficiency in the supply of work positions.

A dimension where the differences by gender are accentuated in the labor market is the weekly worked hours. While about $30 \%$ of the women work less than 40 hours a week, only $15 \%$ of the men work less than 40 hours, making the average working week for women about 5 hours inferior to the men's. This difference has an important impact on the potential of women's income generation, but it is difficult to know if it is result of a choice made by women for a smaller working day or an impediment imposed by the labor market or other factors besides their control.

In the case of differences in the quality of the work positions occupied by men and women, great part of studies have been devoted to measuring the impact of sex discrimination on the controlled differential of individuals' incomes. Comparing people with similar productive characteristics, who have already decided to participate in the labor market and are occupied in similar work positions in the Brazilian metropolitan area, Fernandes and Cavalieri (1998) verify that men receive wages $60 \%$ superior to women's The authors find that this difference is larger among non white than among whites and it tends to decrease as the workers' education increases.

The origin of wage differential by gender has been investigated in several recent studies. Considering that income (personal or the family's) is an accepted measure of welfare, studies on the nature of wage differentials reveal relevant information on the welfare's determinants. In particular, authors have concentrated their attention in knowing (i) if there is occupational segregation in the labor market, that is, if there are work positions which are filled only by men or by women where members of the other sex do not have access; (ii) if the occupational segregation produces differences in wage, in other words, if the predominantly male work positions are on aver- 
Job Placement: Gender Differences and Consequences on Welfare

age better paid than the female (we will call this inter-occupational differences); and (iii) if the salary differences are concentrated inside the occupations (intra-occupational differential).

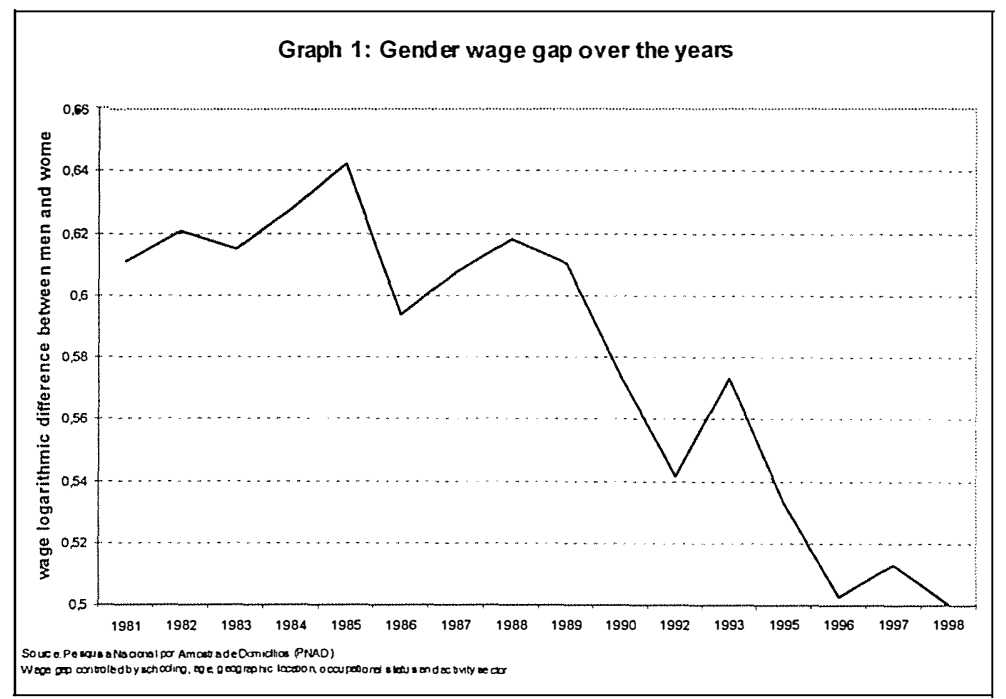

Graph 1 describes the evolution of salary differential for men and women with similar productive characteristics in the recent period in Brazil, and it shows that, even if this differential is high, its magnitude has been decreasing along the years, having decreased about 18\% between 1981 and 1998 .

Oliveira (1998) finds a high degree of occupational segregation in Brazil as a whole (approximately $40 \%$ of occupied women would have to be reallocated to another occupation for their occupational structure to be equaled to men's), and adds that this degree has not altered much along time. Melo (1999) using another occupational classification diverges on this last result, showing that women have begun to occupy positions that were, until then, predominantly occupied by men, although the occupational structure continues to be 
Ricardo Barros, Carlos Corseuill, Daniel Santos and Sérgio Firpo

very different.

Barros et al (1992), analyzing data for urban Brazil in the decade of 80 , concludes that, in spite of the presence of occupational segregation, the occupations with higher degree of feminization don't necessarily present lower medium wages than the masculine occupations. The wage differentials by gender would be, this way, much more concentrated inside the occupations (intra-occupations) than between occupations. In this same study, the authors show that neither age nor education help to explain the intra-occupational wage differential by gender, and that the main determinant of this differential is the combination of formal/informal and employee/self-elployed positions.

Barros et al (1997) confirm the existence of clear occupational segregation in the metropolitan area of São Paulo ${ }^{4}$, with women over-represented in occupations with smaller wage average. In this study, the occupational strategy appeared to be an important factor in wage determination for individuals with low education, representing an important determinant of poverty status of these individuals. Finally, the authors verify that intra-occupational wage differences represent about $1 / 3$ of the total wage differential by sex.

In another type of approach, Camargo and Serrano (1983) also defend that discrimination would be linked to occupational segregation, because big firms with better structured careers prefer to hire men instead of women, restricting the access of the latter to the better jobs.

\section{Methodology.}

The methodology used to capture the effects of change in women's job placement consists on non parametric counterfactual

\footnotetext{
${ }^{4}$ The period studied by the authors are the years of 1983-93.
} 
exercises. In these exercises, we compared the welfare distributions and the distributions of income generation capacity in society, estimated when we simulated an alteration in how women matches jobs, with the original levels.

To implement this procedure three types of information are needed. First it is essential to define welfare and the capacity of income generation. Second it is necessary to determine the ideal women's job placement considering the use of their human capital. Finally it is necessary to have variables that permit us to characterize job placement.

In this paper an individual's welfare will always be associated with his family members per capita income ${ }^{5}$. The individual's income generation capacity will be represented by the income of his main job ${ }^{6}$. Indexes of insufficiency and inequality obtained from the distribution of these attributes will be used as indicators of social welfare and income capacity.

In a complementary way we will assume that the conditions which prevail for men are an appropriate estimate of the ideal job placement for women. Finally, women's job placement will be described by their hourly wage, weekly worked hours and occupational structures. Therefore we will estimate results for insufficiency and inequality of income related to simulated situations where women experience working days, occupational structures and wage levels similar to men's.

To isolate the effect of alterations on women's job placement characteristics on wages we will control our simulations by education

\footnotetext{
${ }^{5}$ Because of a limitation of data base used in this paper we cannot consider income derived from sources other than labor. The labor income of individuals that are less than 10 years old is also not considered.

${ }^{6}$ It is convenient to consider only the main job because it allows us to simulate situations where women occupy work posts similar to men's, like in simulation (c), described in the following section.
} 
level and the individual's occupational group. Other characteristics are frequently analyzed in studies on wage determination, however these two have been pointed as the most important ${ }^{7}$. Notice, however, that most of the variables that could be used for wage control are implicit considered in the analysis. Regarding geographical location we only analyze the metropolitan area of So Paulo. The great advantage of this methodology is the absence of any hypothesis on the functional form that relates wages with its explanatory variables.

In this case we will be estimating the impact on welfare for the society of São Paulo of a new pattern of job placement for women, keeping their education differentials in relation to men constant.

\subsection{Simulations.}

Three simulations were made to see how the poverty and inequality indicators would behave in the following situations:

(a) women's hourly wage being equal to the men's with similar education and occupation;

(b) hourly wage and the working journey of the women being equal to men's with similar education and occupation;

(c) hourly wage, the working journey and the women's occupational structure being equal to men's. The income distribution resulting from simulation (b) works as starting point for simulation (c).

Simulations (a) and (b) consist basically on the transposition of the men's education return curves to the women, controlled by the occupational group. In the case of simulation (a), we allow for differences in participation, while in simulation (b) we do not. Since

${ }^{7}$ See Ramos e Vieira (1996), Fernandes (1996), Barros e Ferreira (1999), Cavalieri e Fernandes (1998), Barros e Reis (1989), amongst others. 
the hour wage and the working day is larger for men than for women, the simulations are used to identify the relative importance of one and another variable on the welfare. The control by occupational group eliminates the effect of wage inequality among people with the same education inside the occupations, making the result of these simulations reflect the impact of wage differences by intra-occupation gender on inadequacy and distribution of income.

In the case of simulation (c), besides transposing men's education return curve to women, men's occupational structure is also imposed as a pattern for the whole occupied population. In this way, an effect of neutralization of the occupational segregation is added to the previous simulations, by equalizing the distributions of both populations for occupational group ${ }^{10}$. As seen previously, occupational segregation on income doesn't seem to affect income so much, because wages in the occupations with higher feminization are not really lower than wage in "male" occupations. However, women's high representativeness in groups with wages below average (especially domestic services) can affect income distribution.

In operational terms in simulation (a) each women's hour wage is constructed by the following expression:

$$
W_{i}^{*}=W_{i}\left(\frac{W_{H / j, k}}{W_{M / j, k}}\right)
$$

where $W_{i}$ is the hourly wage of the women $i, W_{H}$ is the average wage among men, $W_{M}$ is the medium wage among women, and subscript $j$ and $k$ indicate, respectively, the occupational group and the

\footnotetext{
${ }^{10}$ Even in this simulation men and women's average wage don't necessarily have to coincide. That's because the educational composition inside each occupational group can be different, and the simulation imposes that wages must be the same only in groups that are homogeneous in educational level and occupational group, simultaneously.
} 
educational level of the woman in subject. An implicit hypothesis in this simulation is that changes in the hourly wage of a certain socioeconomic group (defined as a homogeneous group considering gender, educational level and occupational group) doesn't affect the wages of other groups.

We can then obtain the labor income of each woman with this new hourly wage:

$$
R_{i}^{a}=H_{i} W_{i / j, k}^{*}
$$

where $H_{i}$ represents the amount of worked hours.

In simulation (b) the counter factual income was calculated the following way:

$$
R_{i}^{b}=W_{i} H_{i}\left(\frac{R_{H / j, k}}{R_{M / j, k}}\right)
$$

where $R_{i}$ is the $i$ women's labor income, $R_{H}$ and $R_{M}$ are, respectively, men and women's average incomes and $j$ and $k$ are interpreted the same way as in the previous simulations ${ }^{11}$.

In none of the simulations the hourly wage/average income of the female population is necessarily identical to the men's. That's because the educational composition / occupational of both populations can differ (probably benefiting the women, that have larger educational level). The more convex the education return curve, the bigger will be the impact of educational inequality on income inequality. Cavalieri and Fernandes (1998) show that this curves is more convex among women than among men, suggesting that one of the impacts of these simulations should be the reduction in income

\footnotetext{
${ }^{11}$ In appendix 1 we present a simulation similar to simulation (b). The difference is that, while in simulation (b) women's income distribution is moved so as to present the same distribution average as the men's wage, the simulation in the appendix moves the distributions of hour wage and female working day separately to the respective male averages. The results are quite similar.
} 
inequality. The final result depends, however, on the differences in the relation among revenues and occupational group for men and women.

Finally, in simulation (c) we can write the joint distribution of the population of occupied women by labor income and occupational group by the following expression:

$$
F_{M}(s, R b)=F_{M}(R b \mid s) F_{M}(s)
$$

where $F_{M}(R b \mid s)$ represents the distribution of women by labor income conditioned to the occupational group, and $F_{M}(s)$ represents the women's marginal distribution by occupational group.

The simulation consists in redistributing women among the occupational groups so that they have the same distribution as men, without altering the distribution of women's labor income inside each group. In other words, we will have:

$$
F_{M}(s, R b)^{*}=F_{M}(R b \mid s) F_{H}(s)
$$

where $F_{H}(s)$ represents the marginal distribution of men by occupational group.

Ideally, it would be interesting to know how the redistribution of women among the groups would also affect the distribution of women according to labor income of each occupational group and include this effect in the simulations. However, in general we only know the impact on the average income of each group. So, it is necessary to suppose that the income distribution of each group remains unaffected in spite of the fact that the size of the group and it's average income has been altered. A form of guaranteeing the validity of this hypothesis is to make sure that the workers that leave the group are selected independently of their income level and that those that 
Ricardo Barros, Carlos Corseuill, Daniel Santos and Sérgio Firpo

enter the group receives an income level chosen randomly according to the income distribution of the destined group.

Operacionally, what we did in this study was to follow two stages:

(i) The workers that will be removed from each group are chosen randomly;

(ii) Each removed female worker is sent to the occupational group with the immediately higher salary level. The criteria for the ordination of the groups is the average wage of men with 5-8 years of study.

(iii) Each worker that is reallocated to a new group receives the necessary income to preserve the relative position that he had in the income distribution of his previous group.

As reallocated workers are chosen randomly in the origin, this procedure guarantees that the chosen wage in the destiny is also random and therefore doesn't affect the income distribution in the origin and in the destiny.

In order to analyze the results of these simulations we supposed that the alterations imposed in the pattern of woman's job placement would not have any effect on men's pattern.

All the simulations affect the income distribution coming from labor among occupied individuals. Besides reporting results related to this income distribution, the family income distribution results will also be reported. For this second distribution we assumed that the status of employed, unemployed or inactive of family members is not affected by the change in women job placement.

\section{Analysis of the results.}

In this section some estimations of the stylized facts shown in section 2 and studied by other authors will be shown, as well as the results of the simulations described in section 3 . 


\subsection{Empiric preliminaries.}
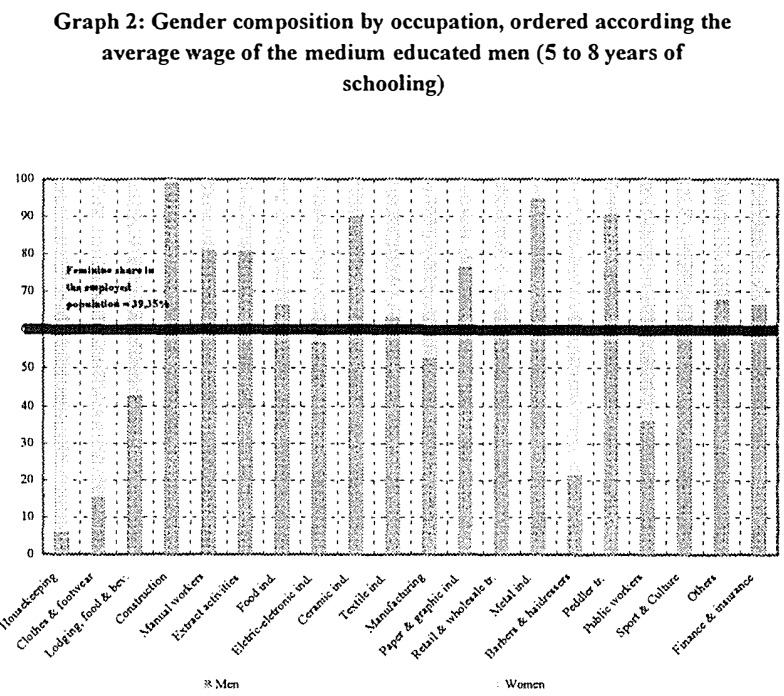

Sorre: Perquiss Merual de Emprego (PME) 1996, 1997 and 1998

Table 2: Gender composition by occupation

\begin{tabular}{lcc}
\hline Occupation & Men & Women \\
\hline Retail and wholesale trade & 13,78 & 15,18 \\
Peddler trade & 8,47 & 1,35 \\
Construction & 10,27 & 0,11 \\
Financial,brokerage and insurance services & 1,68 & 1,30 \\
Barber's shop and beauty services & 0,42 & 2,38 \\
Housekeeping and general domestic services & 0,60 & 14,19 \\
Bars, restaurants and hotel services & 2,64 & 5,44 \\
Public services & 4,18 & 11,33 \\
Sports and culture & 1,37 & 1,40 \\
Clothes making and footwear & 0,62 & 5,22 \\
Extracts activities & 0,26 & 0,09 \\
Food and tobacco industry & 0,15 & 0,11 \\
Ceramic industry,cement,rubber and wood goods & 2,81 & 0,48 \\
Eletric-eletronic industry & 0,30 & 0,35 \\
Graphic and paper industry & 1,14 & 0,53 \\
Metal industry & 6,91 & 0,57 \\
Textile industry & 0,45 & 0,41 \\
Generic occupations of production & 19,12 & 26,71 \\
Manual labor & 13,93 & 4,94 \\
Others & 10,92 & 7,91 \\
\hline
\end{tabular}

Source: Pesquisa Mensal de Emprego (PME) 1996, 1997 and 1998. 
Using a similar category as the one used by Barros et al (1997), we can observe that in most activity groups, women's participation is much higher or much lower than it's representativeness in the occupied population. Among the twenty groups used in this study, in only eight groups the women's representation differs from their representation in the occupied population in less than $10 \%$, as shown in Graph 2. This elevated segregation degree can also be evidenced by verifying that the 10 most feminine occupations (where the percentage of women compared to the total of occupied people is bigger) represent more than $80 \%$ of female employment but only a little more than $40 \%$ of male employment. In a similar way, the 10 most masculine occupations represent less than $20 \%$ of female employment and almost $60 \%$ of male employment (see Graph 3 ).

Another point that can be illustrated in Graph 2 is how differences in occupational insertion are the result of differences in preferences or the result of impediments imposed by the labor market. In this graph, the occupational groups are ordered according to the average wage of men with medium educational level ( 5 to 8 years of study $)^{12}$, making it possible to verify if the female occupations are worse or just different from the male ones. According to this ordination, we estimated the proportion of men and women in low income occupations. The results obtained indicate that, except for the high incidence of women in domestic work, there is little evidence that remuneration in female predominant occupations are inferior to male predominant ones.

\footnotetext{
${ }^{12}$ The male predominant occupational groups were: extract activities; manual labor; metal industry; graphic and paper industry; food and tobacco industry; ceramic industry, wood, cement and rubber goods; retail and wholesale trade; financial, brokerage and insurance services; and construction. The most feminine groups were: electric-electronic industry; textile industry; clothes making and footwear; generic occupations of production; peddler trade; barber's shop and beauty services ; housekeeping and general domestic services; bars, restaurants and hotel services; public services; sports and culture.
} 
Job Placement: Gender Differences and Consequences on Welfare

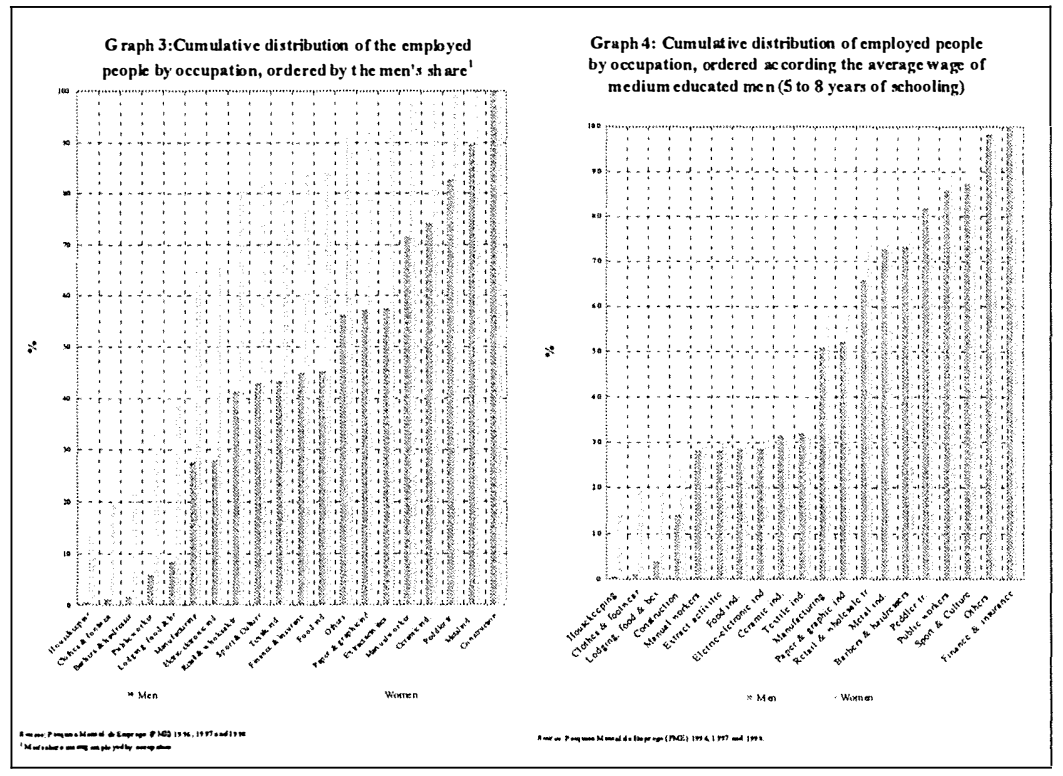

In fact, as shown in Graph 4, the proportion of men and women occupied in groups with average wage below the masculine median is very close, with the difference being inferior to $10 \%$. Besides this, $22 \%$ of women and men are in occupations with average income above $\mathrm{R} \$ 700^{13}$ like public services, sports, culture and financial services. In short, the presented numbers indicate that, although there is strong evidence that women's occupational structure is very different from men's, there are no indications that occupations with a larger feminization degree are inferior to men's where wage is concerned. Thus, the hypothesis that women's distribution among occupations should necessarily reflect access restrictions to job opportunities in groups that remunerate better doesn't find a clear empiric back-up, and the hypothesis that the salary differences appear inside the occupational groups becomes more feasible.

\footnotetext{
${ }^{13}$ Values of July of 1997.
} 
A form of summarizing the degree of inferiority of the female salary structure consists on contrasting which would be the average female and male wage if the average salary in each occupation was the male wage for average schooled workers. When this difference was estimated, the result indicated a male superiority of only $0,5 \%$ when domestic service is excluded and of $5 \%$, when the domestic service is included.

Table 3a: Wage by occupation and educational level

\begin{tabular}{|c|c|c|c|c|}
\hline Occupation & to 4 yea & schooling & 5 to 8 & of schooling \\
\hline & Men & Women & Men & Woman \\
\hline Retail and wholesale trade & 2,82 & 2,09 & 3,60 & 2,43 \\
\hline Peddler trade & 3,79 & 3,75 & 3,74 & 3,65 \\
\hline Construction & 2,61 & 1,67 & 2,65 & 1,74 \\
\hline Financial,brokerage and insurance services & 5,07 & 5,82 & 6,96 & 4,25 \\
\hline Barber's shop and beauty services & 3,32 & 2,62 & 3,48 & 2,66 \\
\hline Housekeeping and general domestic services & 1,87 & 1,97 & 2,42 & 1,90 \\
\hline Bars, restaurants and hotel services & 2,56 & 1,92 & 2,57 & 1,99 \\
\hline Public services & 3,78 & 3,45 & 4,47 & 3,49 \\
\hline Sports and culture & 6,06 & 4,51 & 5,86 & 4,06 \\
\hline Clothes making and footwear & 2,68 & 1,91 & 2,56 & 2,04 \\
\hline Extracts activities & 1,78 & 0,74 & 2,66 & 2,76 \\
\hline Food and tobacco industry & 2,29 & 2,32 & 2,71 & 2,08 \\
\hline Ceramic industry,cement, rubber and wood goods & As 2,99 & 1,80 & 3,08 & 2,02 \\
\hline Eletric-eletronic industry & 2,93 & 2,45 & 2,90 & 1,91 \\
\hline Graphic and paper industry & 3,60 & 2,07 & 3,87 & 2,31 \\
\hline Metal industry & 3,75 & 2,20 & 3,99 & 2,25 \\
\hline Textile industry & 3,14 & 1,75 & 3,28 & 2,05 \\
\hline Generic occupations of production & 4,04 & 2,67 & 3,87 & 2,59 \\
\hline Manual labor & 2,42 & 1,61 & 2,55 & 1,73 \\
\hline Others & 5,27 & 3,46 & 5,86 & 3,60 \\
\hline
\end{tabular}

Source: Pesquisa Mensal de Emprego (PME) 1996, 1997 and 1998.

Dec. 1998 values. 
Job Placement: Gender Differences and Consequences on Welfare

Table 3b: Wage by occupation and educational level

\begin{tabular}{lcccc}
\hline Occupation & $\begin{array}{c}9 \text { to } 11 \text { years of schooling } \\
\text { Men }\end{array}$ & $\begin{array}{c}\text { + } 11 \text { years of schooling } \\
\text { Wen }\end{array}$ & $\begin{array}{c}\text { Woman } \\
\text { Men }\end{array}$ \\
\hline Retail and wholesale trade & 5,13 & 3,12 & 10,53 & 6,29 \\
Peddler trade & 5,48 & 4,19 & 11,18 & 7,35 \\
Construction & 3,43 & 4,58 & 16,24 & 6,86 \\
Financial, brokerage and insurance services & 8,55 & 6,59 & 17,17 & 11,07 \\
Barber's shop and beauty services & 5,28 & 3,68 & 3,70 & 3,77 \\
Housekeeping and general domestic services & 3,07 & 1,72 & 2,04 & 2,65 \\
Bars, restaurants and hotel services & 2,63 & 2,24 & 8,81 & 5,25 \\
Public services & 5,48 & 4,59 & 15,15 & 9,01 \\
Sports and culture & 7,24 & 7,41 & 11,30 & 10,56 \\
Clothes making and footwear & 2,69 & 2,23 & 3,06 & 4,44 \\
Extracts activities & 9,06 & 4,11 & 20,37 & 5,35 \\
Food and tobacco industry & 2,71 & 2,24 & 9,59 & 4,40 \\
Ceramic industry, cement,rubber and wood goods & 3,30 & 2,46 & 6,19 & 8,68 \\
Eletric-eletronic industry & 3,95 & 2,18 & 8,02 & 3,09 \\
Graphic and paper industry & 4,48 & 2,90 & 6,47 & 6,20 \\
Metal industry & 4,88 & 2,76 & 6,88 & 4,74 \\
Textile industry & 3,49 & 2,08 & 5,04 & 2,83 \\
Generic occupations of production & 5,71 & 3,71 & 14,60 & 9,05 \\
Manual labor & 3,44 & 2,19 & 7,14 & 6,19 \\
Others & 9,36 & 6,09 & 17,66 & 10,65 \\
\hline
\end{tabular}

Source: Pesquisa Mensal de Emprego (PME) 1996, 1997 and 1998.

Dec. 1998 values.

Finally, we have to document the wage differences by gender in the occupational groups. With this aim, Table 3 shows the average wage of men and women by occupation and educational level ${ }^{14}$. This table reveals that in most cases men's wages are superior to women's. In fact, only in $5 \%$ of the considered cases the women's average wage was $10 \%$ superior to men's, while in $81 \%$ of the cases the opposite happened. With the objective of obtaining a summary statistics of the magnitude of these salary differences, we calculated the average of these differences using the male and female occupationaleducational composition. In both cases the results indicate that the average wage difference between men and women in the same occupation and with the same education is near $50 \%$.

\footnotetext{
${ }^{14}$ We must present in this table the standard error for the estimate of the average and it might be worth to include also, or instead of, the confidence interval of $90 \%$.
} 
Ricardo Barros, Carlos Corseuill, Daniel Santos and Sérgio Firpo

Graph 5 shows that, although there is a tendency for a positive relation between the degree of masculinization of the occupation of an occupational group and the salary hiatus between men and women, that is, although a tendency exists for the women's salary inferiority to be smaller in the most feminine occupations, this relation is relatively weak.

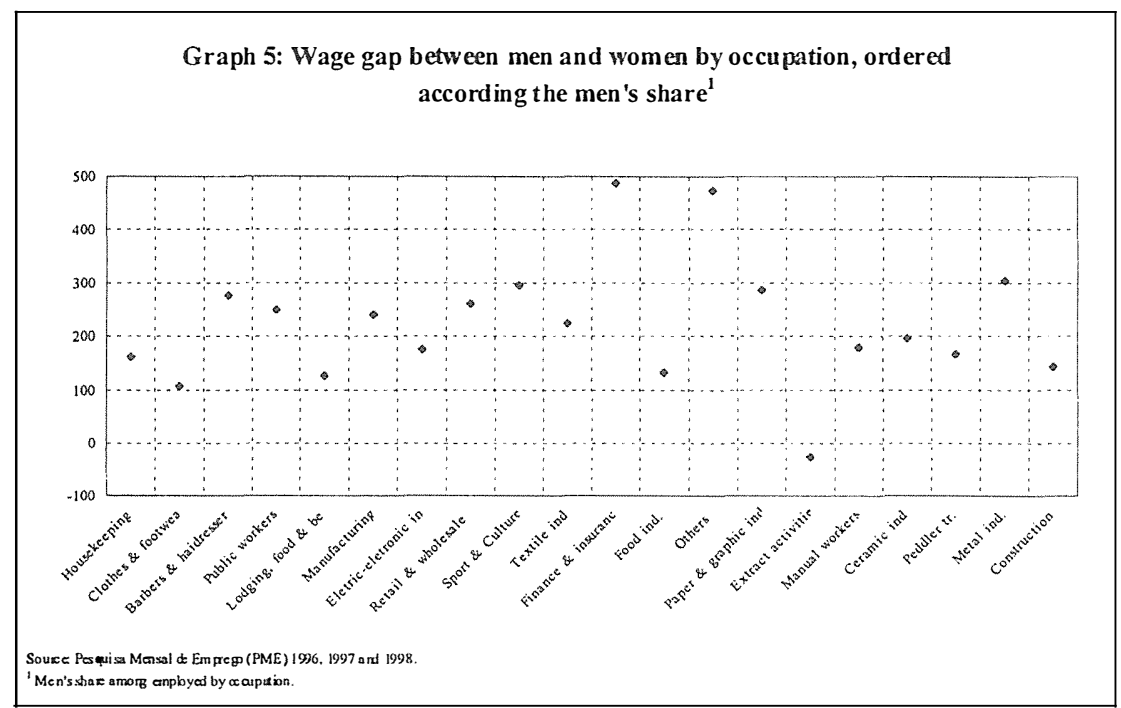


Job Placement: Gender Differences and Consequences on Welfare

\subsection{Results of the simulations.}

All the analysis of this section will be based on results that were obtained using the Monthly Employment Research of IBGE (PME / IBGE). Our analysis universe corresponds to workers of the metropolitan area of So Paulo that were employed in any month between January of 1996 and December of 1998.

The results will be expressed through three measures of income inequality and three measures of poverty or insufficiency in the capacity of income generation ${ }^{15}$. The inequality measures used are the Coefficient of Variation and the indexes of Theil and Gini.

The poverty measures or insufficiency are the P0, P1 and P2 indexes; proposed by Foster, Greer and Thorbecke ${ }^{16}$. The indicators of class $\mathrm{P}(\mathrm{n})$ can be interpreted as incidence measures and poverty intensity in a population, that differ from each other by attributing different proportional weights to each poor person's necessities. The bigger the $\mathrm{n}$, the larger the convexity of the relation weight versus the distance income- poverty line, and more sensitive the indicator is to the intensity of poverty ${ }^{17}$. The indicators $\mathrm{P} 1$ and $\mathrm{P} 2$ are, therefore, more sensitive to the intensity of poverty / inadequacy of income than P0 (that gives the same weight to each poor person, independently of the distance between this person's earnings and the poverty line), and for this reason are used as alternative measures.

\footnotetext{
${ }^{15}$ Originally, P0, P1 and P2 were conceived to be poverty indicators. In fact, when we analyse the impacts on family revenue per capita, we refer to these indicators as poverty indicators. However, the interpretation becomes a little different when we analyse the impact on personal revenue, because people that receive less than the poverty line are not necessarily poor. In this case, it would be correct to name it an indicator of income generation insufficiency. We will call these indicators simply poverty indicators, except in the comments made on the results, in order to make reading easier.

${ }^{16}$ Foster, Greer and Thorbecke (1984).

${ }^{17}$ For a discussion on the use of these indexes, see Hoffmann (1998).
} 
For the calculation of the poverty indexes / incapacity of income generation, three alternative inadequacy lines were used. In the case of welfare distribution the poverty lines used were 0,$5 ; 1$ and 2 minimum wages of July 1997, in other words, $\mathrm{R} \$ 60,00 ; \mathrm{R} \$ 120,00$ and $\mathrm{R} \$ 240,00$ of July of 1997 respectively ${ }^{18}$. In the case of income generation capacity distribution the inadequacy levels considered were of 2, 3 and 5 minimum wages of July of 1997 , in other words, $\mathrm{R} \$ 240,00$; $\mathrm{R} \$ 360,00$ and $\mathrm{R} \$ 600,00$ of July of 1997 respectively. These values should be higher as they do not consider the distribution of resources among members of the family.

\subsubsection{Distribution of the capacity of generation of income.}

Tables $4 \mathrm{a}$ and $4 \mathrm{~b}$ show the results of the simulations described in section 3 on the insufficient measures and relative inequality of the distribution of income generation capacity (or income distribution of the main job). Table 4a shows the effects on the total of the occupied population while table $4 \mathrm{~b}$ shows only the effects on occupied women. When analyzing the impacts on the occupied population and occupied women, we can find out if possible redistribution impacts derived from our simulations occur because of changes in the wage deferential between sexes or because of the inequality degree intrasex. So, the elimination of the differences of revenues by sex inside homogeneous cells in educational level and occupational group - that would tend to reduce the salary differential among sexes ${ }^{19}$ - can also be causing variations in the degree of inequality intra-sexes (because men and women are distributed in a different way among the cells).

\footnotetext{
${ }^{18}$ These values were deflated by INPC-R for the other months of the analyzed period.

${ }^{19}$ Although not even this tendency necessarily happens. If the proportion of occupied women in the categories where men's average wage is bigger is sufficiently large, there could be an inversion of the wage differential by sex which will cause a raise in absolute value of this differential.
} 


\section{Job Placement: Gender Differences and Consequences on Welfare}

Table 4a: Inequality and insufficiency indicators - observed and simulated

\begin{tabular}{|c|c|c|c|c|}
\hline \multirow{2}{*}{ Indicators } & \multicolumn{4}{|c|}{ (a) Wage distribution among employed individuals } \\
\hline & Original & (a)Wage & (b) Wage ${ }^{*}$ hours & $\begin{array}{l}\text { (c) Wage }{ }^{*} \text { hours }+ \\
\text { ocupation }\end{array}$ \\
\hline \multicolumn{5}{|l|}{ Inequality } \\
\hline Theil index & 0,61 & 0,62 & 0,61 & 0,59 \\
\hline Gini Coefficient & 0,56 & 0,57 & 0,56 & 0,56 \\
\hline Variation coefficient & 1,11 & 1,09 & 1,08 & 1,03 \\
\hline \multirow{2}{*}{\multicolumn{5}{|c|}{$\begin{array}{l}\text { Income insufficiency } \\
2 \text { Minimum wages (July } 1997)\end{array}$}} \\
\hline & & & & \\
\hline P0 & 0,25 & 0,23 & 0,21 & 0,21 \\
\hline P1 & 0,15 & 0,15 & 0,13 & 0,13 \\
\hline P2 & 0,12 & 0,13 & 0,12 & 0,11 \\
\hline \multicolumn{5}{|c|}{3 Minimum wages (July 1997) } \\
\hline PO & 0,42 & 0,37 & 0,34 & 0,34 \\
\hline P1 & 0,21 & 0,20 & 0,18 & 0,18 \\
\hline P2 & 0,15 & 0,16 & 0,14 & 0,14 \\
\hline \multicolumn{5}{|c|}{5 Minimum wages (July 1997) } \\
\hline $\mathrm{PO}$ & 0,64 & 0,59 & 0,57 & 0,56 \\
\hline P1 & 0,34 & 0,32 & 0,29 & 0,29 \\
\hline P2 & 0,24 & 0,22 & 0,20 & 0,20 \\
\hline \multicolumn{5}{|c|}{ Table 4b: Inequality and insufficiency indicators - observed and simulated } \\
\hline \multicolumn{5}{|c|}{ (a) Wage distribution among employed individuals } \\
\hline \multirow[t]{2}{*}{ Indicators } & & & & \\
\hline & Original & (a)Wage & (b) Wage * hours & $\begin{array}{l}\text { (c)Wage }{ }^{*} \text { hours }+ \\
\text { ocupation }\end{array}$ \\
\hline \multicolumn{5}{|l|}{ Inequality } \\
\hline Theil index & 0,56 & 0,65 & 0,61 & 0,56 \\
\hline Gini Coefficient & 0,54 & 0,58 & 0,56 & 0,55 \\
\hline Variation coefficient & 1,01 & 1,09 & 1,05 & 0,92 \\
\hline \multicolumn{5}{|l|}{ Income insufficiency } \\
\hline \multicolumn{5}{|c|}{2 Minimum wages (July 1997) } \\
\hline $\mathrm{PO}$ & 0,31 & 0,27 & 0,21 & 0,20 \\
\hline $\mathrm{P} 1$ & 0,17 & 0,18 & 0,14 & 0,13 \\
\hline P2 & 0,14 & 0,16 & 0,12 & 0,11 \\
\hline \multicolumn{5}{|c|}{3 Minimum wages (July 1997) } \\
\hline $\mathrm{PO}$ & 0,53 & 0,39 & 0,32 & 0,32 \\
\hline $\mathrm{P} 1$ & 0,26 & 0,23 & 0,18 & 0,17 \\
\hline P2 & 0,18 & 0,18 & 0,14 & 0,14 \\
\hline \multicolumn{5}{|c|}{5 Minimum wages (July 1997) } \\
\hline $\mathrm{PO}$ & 0,74 & 0,61 & 0,55 & 0,54 \\
\hline $\mathrm{P} 1$ & 0,41 & 0,34 & 0,28 & 0,28 \\
\hline P2 & 0,29 & 0,25 & 0,20 & 0,20 \\
\hline
\end{tabular}

Source Pesquisa Mensal de Emprego (PME) 1996/97/98. 
In the whole occupied population, the effect associated to the hour wage (simulation (a)) it is practically null in inequality terms, once the indicators alter in just one percentile point (except the variation coefficient that reduces two percentile points). In the case of income generation insufficiency measures, the values present a reduction tendency, and this pattern is more accentuated for larger inadequacy lines. Besides, the indicator that suffers larger falls is P0, which doesn't consider variations in the intensity of income generation incapacity. When we use the indicators P1 and P2, we observe that the reduction is not so significant. The results minimize the impression caused by Table 3 (subsection 4.1), which showed significant salary differences in most of the cells of the occupational / homogeneous educational level group.

This fact can be indicating that the discrimination degree for gender in the extremely badly paid occupations or in the inferior levels of education (inequality intra-cells ${ }^{20}$ ) is low, or that the women's proportion in this occupation type is relatively small (favoring the increase of the differential among cells to compensate the reduction of the inequality intra-cells), so that for as large as these changes in women's job placement are the inadequacy indicators for the population as a whole will not be very much affected. Another explanation would be that the curve of return rates to women's education is smoother than the men's, which would make the effect of educational inequality on income distribution smaller for women, but the evidences from other studies don't back up this hypothesis.

Table $4 \mathrm{~b}$ shows that the effects of the simulations are more accentuated if we consider only the women's sub-universe, as expected once the group is directly affected by simulated alterations. It is worth mentioning the increase in inequality among occupied women when we alter the hour wage of this group, in other words, when

${ }^{20}$ By cells, we understand homogeneous groups in educational level and occupational group. 
these start to receive the equivalent to what men of the same educational level and in the same occupation earn, a larger dispersion appears in the considered revenues.

With this result, the explanation that the elimination of differentials in the salary structure for occupational group / educational level elevates the inequality intra-sexes and that it would compensate the inequality reduction among sexes to generate a practically null result on income inequality of the main job of the occupied population as a whole becomes quite reasonable. As the inequality inside each occupational group / educational level cell is not being altered (because we are simply moving the average of the distributions inside these cells and not the dispersion), we can conclude that the inequality between cells is larger among men than among women, and the imposition of the distribution of medium wages for male cells to the women would be the cause of the increase observed in the female inequality.

We also see that the incapacity of income generation reduces sensibly, mainly when the insufficiency line considered is the one of 3 minimum wages, pointing out the existence of strong discrimination by gender among cells with low remuneration. The result was foreseen, because, as made clear in section 2, the masculine wages are larger than the feminine ones in the great majority of cases.

The effect of the working day on distributive inequality in the total population, is practically inexistent. In none of the three indicators analyzed for distribution the differences among the numbers of the simulations (a) and (b) they decreased more than 1 point percentile. When we considered only the feminine population as the analyzed universe, we verified that the observed increase of inequality is about 50

The effects of alterations in the occupational structure on the distribution of the considered income are illustrated in the last col- 
Ricardo Barros, Carlos Corseuill, Daniel Santos and Sérgio Firpo

umn of Tables $4 \mathrm{a}$ and $4 \mathrm{~b}$ (simulation (c)). The results show that the alteration of the occupational structure practically doesn't affect the indicators of inequality of the population as a whole, but they improve the distribution of personal income sensibly among women, denoting that the occupational segregation has an effect on income inequality of the main job among women (inequality intra-sexes). Comparing with the descriptive results obtained previously, we can infer that the positive result of income dispersion focus exactly on the workers' redistribution among the 4 occupational groups with worse remuneration. For Graph 4, we observed that women are clearly super-represented in the segments of domestic services; clothes and footwear; and hostelry services, while men are super-represented in the building site, with superior medium remuneration compared to the other three groups.

On the other hand, this change has limited effect in inadequacy terms in the capacity of income generation. This result is observed so much for the totality of the occupied ones as for only the occupied women.

\subsubsection{Welfare distribution.}

Tables 5a to 5b show the measures of poverty and inequality when used for the welfare distribution associated to the alterations of the hour wage, working day and occupational structures, as well as for the original distributions for comparison effects. Table 5a shows the effects on the total population and table $5 \mathrm{~b}$ shows the effect on the universe of the feminine population. 
Job Placement: Gender Differences and Consequences on Welfare

Table 5a: Inequality and poverty indicators - observed and simulated

\begin{tabular}{|c|c|c|c|c|}
\hline \multicolumn{5}{|c|}{ (a) Per capita household income distribution } \\
\hline \multicolumn{5}{|l|}{ Indicators } \\
\hline & Original & (a)Wage & (b) Wage ${ }^{*}$ hours & $\begin{array}{c}\text { (c)Wage } \text { Wours }+^{*} \\
\text { ocupation }\end{array}$ \\
\hline \multicolumn{5}{|l|}{ Inequality } \\
\hline Theil index & 0,72 & 0,75 & 0,74 & 0,69 \\
\hline Gini Coefficient & 0,61 & 0,62 & 0,62 & 0,60 \\
\hline Variation coefficient & 1,25 & 1,27 & 1,26 & 1,17 \\
\hline \multicolumn{5}{|l|}{ Poverty } \\
\hline \multicolumn{5}{|c|}{ 0,5 Minimum wage (July 1997 ) } \\
\hline PO & 0,22 & 0,21 & 0,20 & 0,19 \\
\hline $\mathrm{P} 1$ & 0,16 & 0,16 & 0,16 & 0,15 \\
\hline P2 & 0,15 & 0,15 & 0,15 & 0,14 \\
\hline \multicolumn{5}{|c|}{1 Minimum wage (July 1997) } \\
\hline $\mathrm{PO}$ & 0,37 & 0,35 & 0,33 & 0,31 \\
\hline $\mathrm{P} 1$ & 0,23 & 0,22 & 0,21 & 0,20 \\
\hline P2 & 0,19 & 0,18 & 0,18 & 0,17 \\
\hline \multicolumn{5}{|c|}{2 Minimum wages (July 1997) } \\
\hline $\mathrm{PO}$ & 0,61 & 0,58 & 0,56 & 0,53 \\
\hline P1 & 0,37 & 0,35 & 0,33 & 0,31 \\
\hline P2 & 0,28 & 0,27 & 0,26 & 0,23 \\
\hline
\end{tabular}

Table 5b: Inequality and poverty indicators - observed and simulated

(a)Per capita household income distribution among women

\begin{tabular}{|c|c|c|c|c|}
\hline \multicolumn{5}{|l|}{ Indicators } \\
\hline & Original & (a)Wage & (b) Wage ${ }^{*}$ hours & $\begin{array}{c}\text { (c) Wage }{ }^{*} \text { hours }+ \\
\text { ocupation }\end{array}$ \\
\hline \multicolumn{5}{|l|}{ Inequality } \\
\hline Theil index & 0,72 & 0,76 & 0,76 & 0,70 \\
\hline Gini Coefficient & 0,61 & 0,62 & 0,62 & 0,61 \\
\hline Variation coefficient & 1,21 & 1,25 & 1,25 & 1,13 \\
\hline \multicolumn{5}{|l|}{ Poverty } \\
\hline \multicolumn{5}{|c|}{ 0,5 Minimum wage (July 1997 ) } \\
\hline Po & 0,23 & 0,22 & 0,21 & 0,20 \\
\hline $\mathrm{P} 1$ & 0,18 & 0,18 & 0,17 & 0,16 \\
\hline P2 & 0,16 & 0,17 & 0,16 & 0,16 \\
\hline \multicolumn{5}{|c|}{1 Minimum wage (July 1997) } \\
\hline PO & 0,39 & 0,36 & 0,34 & 0,32 \\
\hline P1 & 0,24 & 0,24 & 0,22 & 0,21 \\
\hline $\mathrm{P} 2$ & 0,20 & 0,20 & 0,19 & 0,18 \\
\hline \multicolumn{5}{|c|}{2 Minimum wages (July 1997) } \\
\hline PO & 0,63 & 0,59 & 0,56 & 0,53 \\
\hline $\mathrm{P} 1$ & 0,38 & 0,36 & 0,34 & 0,32 \\
\hline P2 & 0,29 & 0,28 & 0,27 & 0,24 \\
\hline
\end{tabular}

Source: Pesquisa Mensal de Emprego (PME) 1996/97/98. 
The effect associated to the hour wage on welfare distribution is the increase of inequality and a moderate fall of poverty. The inequality measures in the total population present increases of one (Gini) to three (Theil) percentile points. The poverty measures tend to present variations of the same magnitude. It is worth to point out that in the lower inadequacy level the variation is insignificant, which means that the welfare of specially poor families is not affected by the considered simulation. The origin of this impact is in the increase of distributive inequality of labor income among women (commented in the previous subsection), transformed by the distribution of family composition, that is, by the way the presence of occupied women in the families varies with income.

The effect associated to the working day, is totally insignificant. The inequality indicators remains constant as well as most of the indexes of insufficiency. Only the indicators related to the highest poverty line reduce one percentile point.

The results of Table 5b regarding the women's universe are basically the ones mentioned above for the total population. In relation to the effect of alteration in the hour wage, inequality increases in a slightly superior magnitude and the insufficiency presents falls a little larger than in the indicators, but the movements are very similar to the ones verified in the total population. In relation to the effect of the working day Table 5b confirms that even among women the indicators don't change significantly.

In relation to the simulations involving alteration of women's occupational structure, two interesting facts come forth. In the first place the effect of alteration in the medium income is in fact quite close to the joined effect of alteration in the hour wage and in the working day (in other words, the average of covariance between hour wage and the duration of the working day in homogeneous socioeconomic groups is close to zero). Comparing both results we can verify 
that no indicator differs in more than one percentile point. The second fact to be pointed out refers to the effect of alteration in the occupational structure. This alteration produces a fall in inequality more than enough to compensate the increase due to alteration of average income. The inadequacy indexes also point a fall, less expressive, however, than the one of inequality.

Table $5 \mathrm{~b}$ also shows that the results for the feminine population are basically the same ones, in spite of us leading only with the universe of people directly affected by changes. The explanation for that is that, when dealing with per capita family income, we are spreading the alterations in women's revenue for all family members.

\section{Conclusion.}

This study tried to estimate the impact on measures of welfare and of capacity of generation of income of a change in the women's job placement, attributing to women an equivalent role to that of the men, making wages, working day and occupational structures compatible. Such impact can be interpreted as the loss of social welfare due to the sub-use of human capital stock from women.

As to income inequality of the main job is concerned, it is observed that the accomplished simulations didn't affect the indicators significantly for the population as a whole, although they had representative effect for the female population. This fact makes us believe that changes in intra-sex inequality tends to be compensated by movements in the opposite direction, the inequality between sexes.

Of the three dimensions of insertion analyzed, the imposition of the average hour wage from men to women (controlled by educational level and occupational group) caused an increase of about $11 \%$ in the indicators of income concentration (indexes of Gini and Theit- $\mathrm{T}$, and Coefficient of Variation) among women. When we also 
included in the simulation the working day, a quick reduction of this concentration may be noticed (approximately 5\%). Finally, when transporting the occupational structure of men to women, we verified a new decrease in distributive inequality $(7 \%$, in average for the three analyzed indicators). Of these results, we may conclude that the differences on the forms of insertion for gender in the labor market don't necessarily imply a superiority of the masculine insertion pattern in distributive terms.

As to where inadequacy of income generation is concerned, we observed that whenever one of the insertion dimensions in women's labor market is made compatible with men's, the proportion of people below the inadequacy line (P0) suffer a reduction (for three values distinct from this line). The most significant variations are related to the working day (for larger insufficiency lines ) and to the hour wage (for the lowest line). The differences in the occupational structure practically didn't affect this indicator. The movement of the other indicators of insufficiency of income tends to accompany $\mathrm{P} 0$, with rare exceptions. Differently from the degree of distributive inequality, it can be said that the pattern of masculine insertion in the labor market presents smaller incidence and inadequacy intensity in the income generation capacity.

The effects on welfare distribution (family income per capita) are much smaller than the effects on distribution of income generation capacity (main job income). This result was expected because the benefits in terms of income generation capacity should be distributed in the ambit of the family, becoming a less significant benefit in welfare terms. The poverty / insufficiency indicators remained practically unaltered, even when only the universe of women was considered. In relation to inequality indicators, it was verified that the compatibilization of men and women's hour wage elevates the dispersion of welfare, while the compatibilization of the respective 
Job Placement: Gender Differences and Consequences on Welfare

occupational structures reduces this dispersion. A possible further study would be to investigate the distribution of revenues between men and women inside the family, and how different types of family structure condition men and women's choices concerning the way they pretend to insert themselves in the labor market.

Submitted in August 2000. Revised in September 2001.

\section{References}

Barros, Ricardo Paes de, Lauro A. Ramos \& Eleonora Santos 1992. "Gender differences in Brazilian labor markets". In: Anais do XX Encontro Nacional de Economia. Campos do Jordo.

Barros, Ricardo Paes de, Ana Flávia Machado \& Rosane Mendona 1997. "A desigualdade da pobreza: estratégias ocupacionais e diferenciais por gênero". IPEA, Texto para Discusso 453.

Barros, Ricardo Paes de [et. al.] 1999. "Family structure and family behavior over the life cycle in Brazil". IPEA, (mimeo).

Barros, Ricardo Paes de \& Francisco Ferreira 1999. "Slippery slope: the increase in the extreme poverty in Brazil". Revista de Econometria 19:2.

Barros, Ricardo Paes de \& José Guilherme Reis 1989. "Um estudo da evolução das diferenças regionais da desigualdade no Brasil". IPEA, Textos para Discussão Interna 178.

Barros, Ricardo Paes de \& Daniel D. Santos 2001. "Mercado de trabalho e bem-estar social". IPEA, (mimeo).

Camargo, J. M. \& Franklin Serrano 1983. "Os dois mercados: homens e mulheres na indústria brasileira. Revista Brasileira de Economia 374:435-448.

Cavalieri, Cláudia \& Reynaldo Fernandes 1998. "Diferenciais de salários por gênero e cor: uma comparação entre as regiões 
Ricardo Barros, Carlos Corseuill, Daniel Santos and Sérgio Firpo

metropolitanas brasileiras". Revista de Economia Política 181(69):158-175.

CEPAL 1997. "La estructura del empleo en los últimos 15 años". In: Panorama Social de América Latina 1997, 43-56.

Fernandes, Alexandre Z 1998. "Oferta de trabalho das mulheres cônjuges nas regiões metropolitanas do Brasil". IPEA, Série Seminários 7.

Fernandes, Reynaldo 1996. "Mercado de trabalho nãoregulamentado: participação relativa e diferenciais de salários. Pesquisa e Planejamento Econômico 263:417-442.

Foster, James, Joel Greer, \& Erik Thorbecke 1984 . "A class of decomposable poverty measures". Econometrica 523:761-766.

Hermeto, Ana Maria 1998. "Segregação ocupacional por sexo no Brasil". IPEA, Série Seminários 13.

Hoffmann, Rodolfo 1998. "Distribuição de renda: medidas de desigualdade e pobreza". EDUSP.

Melo, Hildete 1999. "O desemprego feminino". IPEA (mimeo).

MELO, Hildete 2000. "O trabalho industrial feminino". IPEA, Texto para Discussão 764.

Ramos, Lauro \& Maria Lúcia Vieira 1996. “A relação entre educação e salários no Brasil". In: A economia brasileira em perspectiva, IPEA.

Sachsida, A. \& Paulo Roberto Loureiro 1998. "Homens $\times$ mulheres: substitutos ou complementares no mercado de trabalho?" IPEA, Texto para Discussão 595. 
Job Placement: Gender Differences and Consequences on Welfare

\section{APPENDIX I: An alternative to the simulation. ${ }^{21}$}

With the intention of simulating the effect of the standardization of working day and the women's hour wage simultaneously according to the patterns observed for men, we moved the distribution of the womens main job income (product of the hour wage for the number of worked hours) to the male average in simulation (b). An alternative form of doing that would be to move the distributions of hour wage and women's working day separately for the men's average and recalculate the female income Following the notation of section 3, we define $H^{*}$ as being:

$$
H_{i}^{*}=H_{i}\left(\frac{H_{H / j, k}}{H_{M / j, k}}\right)
$$

where $H_{i}$ is the $i$ womans working day, $H H$ is the mens average working day, $H M$ is the womens average working day and subscript $j$ and $k$ characterize the occupational group and the referred woman's educational level. You can then obtain the labor income of each woman with this new working day:

$$
R_{i}^{b}=H_{i}^{*} W_{i}^{*}
$$

It is worth to point out that this procedure, although very similar to the one described in simulation (b), should not necessarily produce the same results. This is because the product of the averages of the two variables is not necessarily the same as the average of the product of these variables. Tables A1a-b show the results of this simulation which are in fact very similar to the results of simulation (b).

${ }^{21}$ It is easy to show that $R^{c}=R^{b}\left(\frac{R_{H / j, k} W_{M / j, k} H_{M / j, k}}{R_{M / j, k} W_{H / j, k} H_{H / j, k}}\right)$; and therefore $R c \neq R b$. 
Ricardo Barros, Carlos Corseuill, Daniel Santos and Sérgio Firpo

Table Ala: Simulations involving changes in hours and wage separately Wage from main job

\begin{tabular}{|c|c|c|c|c|}
\hline \multirow{3}{*}{ Indicator } & \multicolumn{2}{|c|}{ All occupied } & \multicolumn{2}{|c|}{ Occupied women } \\
\hline & & & & \\
\hline & Original & Simulated & Original & Simulated \\
\hline \multicolumn{5}{|l|}{ Inequality } \\
\hline Theil index & 0,61 & 0,62 & 0,56 & 0,65 \\
\hline Gini Coefficient & 0,56 & 0,57 & 0,54 & 0,58 \\
\hline Variation coefficient & 1,11 & 1,09 & 1,01 & 1,09 \\
\hline \multicolumn{5}{|l|}{ Income insufficiency } \\
\hline \multicolumn{5}{|c|}{2 Minimum wages (July 1997) } \\
\hline PO & 0,25 & 0,22 & 0,31 & 0,24 \\
\hline $\mathrm{P} 1$ & 0,15 & 0,15 & 0,17 & 0,17 \\
\hline P2 & 0,12 & 0,13 & 0,14 & 0,15 \\
\hline \multicolumn{5}{|c|}{3 Minimum wages (July 1997) } \\
\hline $\mathrm{PO}$ & 0,42 & 0,35 & 0,53 & 0,35 \\
\hline $\mathrm{P} 1$ & 0,21 & 0,19 & 0,26 & 0,21 \\
\hline $\mathrm{P} 2$ & 0,15 & 0,15 & 0,18 & 0,17 \\
\hline \multicolumn{5}{|c|}{5 Minimum wages (July 1997) } \\
\hline PO & 0,64 & 0,58 & 0,74 & 0,57 \\
\hline $\mathrm{P} 1$ & 0,34 & 0,30 & 0,41 & 0,31 \\
\hline P2 & 0,24 & 0,22 & 0,29 & 0,23 \\
\hline
\end{tabular}

Table A1b: Simulations involving changes in hours and wage separately Per capita household income

\begin{tabular}{|c|c|c|c|c|}
\hline \multirow{3}{*}{ Indicator } & \multicolumn{2}{|c|}{ Total population } & \multicolumn{2}{|c|}{ Women population } \\
\hline & & & & \\
\hline & Original & Simulated & Original & Simulated \\
\hline \multicolumn{5}{|l|}{ Inequality } \\
\hline Theil index & 0,72 & 0,75 & 0,72 & 0,76 \\
\hline Gini Coefficient & 0,61 & 0,62 & 0,61 & 0,63 \\
\hline Variation coefficient & 1,25 & 1,27 & 1,21 & 1,26 \\
\hline \multicolumn{5}{|l|}{ Income insufficiency } \\
\hline \multicolumn{5}{|c|}{2 Minimum wages (July 1997) } \\
\hline $\mathrm{PO}$ & 0,22 & 0,21 & 0,23 & 0,22 \\
\hline $\mathrm{P} 1$ & 0,16 & 0,16 & 0,18 & 0,18 \\
\hline $\mathrm{P} 2$ & 0,15 & 0,15 & 0,16 & 0,16 \\
\hline \multicolumn{5}{|c|}{3 Minimum wages (July 1997) } \\
\hline Po & 0,37 & 0,34 & 0,39 & 0,35 \\
\hline P1 & 0,23 & 0,22 & 0,24 & 0,23 \\
\hline $\mathrm{P} 2$ & 0,19 & 0,18 & 0,20 & 0,19 \\
\hline \multicolumn{5}{|c|}{5 Minimum wages (July 1997) } \\
\hline PO & 0,61 & 0,57 & 0,63 & 0,57 \\
\hline $\mathrm{P} 1$ & 0,37 & 0,34 & 0,38 & 0,35 \\
\hline P2 & 0,28 & 0,26 & 0,29 & 0,27 \\
\hline
\end{tabular}

Source: Pesquisa Mensal de Emprego (PME) 1996/97/98. 
